\title{
Reproductive Politics in Twentieth-Century France and Britain
}

\author{
JESSE OLSZYNKO-GRYN $^{1 *}$ and CAROLINE RUSTERHOLZ ${ }^{2}$ \\ ${ }^{1}$ Chancellor's Fellow, School of Humanities (History), University of Strathclyde, \\ Lord Hope Building, 141 St James Road, Glasgow G4 OLT, UK \\ ${ }^{2}$ Wellcome Trust Research Fellow, Faculty of History, University of Cambridge, \\ Alison Richard Building, 7 West Road, Cambridge CB3 9DT, UK
}

\begin{abstract}
This special issue adopts a comparative approach to the politics of reproduction in twentieth-century France and Britain. The articles investigate the flow of information, practices and tools across national boundaries and between groups of experts, activists and laypeople. Empirically grounded in medical, news media and feminist sources, as well as ethnographic fieldwork, they reveal the practical similarities that existed between countries with officially different political regimes as well as local differences within the two countries. Taken as a whole, the special issue shows that the border between France and Britain was more porous than is typically apparent from nationally-focused studies: ideas, people and devices travelled in both directions; communication strategies were always able to evade the rule of law; contraceptive practices were surprisingly similar in both countries; and religion loomed large in debates on both sides of the channel.
\end{abstract}

Keywords: Abortion, Assisted conception, Contraception, Family planning, Prenatal genetic screening, In vitro fertilisation (IVF)

Last summer, France paid tribute to Simone Veil (1927-2017). On 1 July 2018, the former health minister and Auschwitz survivor was interred in the Panthéon, the resting place of the country's icons, to become, alongside Marie Curie, one of only five women so honoured. In France, Veil is a household name synonymous with the law she drafted that legalised abortion in 1975. A landmark of feminism and secularism, it became known simply as 'la loi Veil' (the Veil law). Attended by thousands in Paris and broadcast on

* Email addresses for correspondence: jesse.olszynko-gryn@strath.ac.uk, cr523@cam.ac.uk This special issue began as a conference held at the Centre for Research in the Arts, Social Sciences and Humanities (CRASSH), University of Cambridge, in September 2016, and supported by CRASSH and Wellcome (106553) and (088708). We thank the four anonymous reviewers who provided helpful feedback on drafts of this introduction; and all those who participated at the conference, especially Salim Al-Gailani, Jennie Bristow, Fabrice Cahen, Virginie De Luca Barrusse, Lucy Delap, Katherine Dow, Sarah Franklin, Lesley Hall, Cathy Herbrand, Nick Hopwood, Bibia Pavard, Anne-Françoise Praz, Sally Sheldon, Simon Szreter, Laurence Tain and Isabelle Ville. 
state television, the 'panthéonisation' of Simone Veil was a major national event. 'Merci Simone' posters adorned the streets. ${ }^{1}$

Four days later, on 5 July 2018, the Science Museum in London opened a temporary exhibition to mark forty years of in vitro fertilisation (IVF). Louise Joy Brown, the 'first test-tube baby', was born at Oldham General Hospital near Manchester on 25 July 1978, and the exhibition promised to explore the "ten years of experimentation, hundreds of failed attempts and many setbacks' that culminated in her "'miraculous" birth'. IVF: 6 Million Babies Later showcased original scientific notebooks, equipment and press coverage, as well as 'equipment used in an IVF lab today', the 'future of embryo manipulation' and 'ethical questions around this research that continue to be debated'. Beyond the exhibition, Louise Brown's fortieth birthday was celebrated around the world; a collection of letters (including notes of congratulation, but also hate mail), gifts and other mementos kept by her mother was unveiled on her birthday at Bristol Archives. ${ }^{3}$

France's loi Veil and the British 'birth' of IVF represent significant milestones in the history of modern reproduction. The national character of the original events and their more recent commemorations also raise timely questions about the contributions of France and Britain to the politics and technology of reproduction, in the 1970s and today. For this special issue, we have decided to explore reproductive politics in twentieth-century France and Britain, not only because the two countries present historians with a number of productively challenging similarities and differences, but also because much of the best scholarship on France is accessible only to readers of French; a situation we hope this special issue will begin to alleviate.

\section{Political Histories of Reproduction}

'Reproductive politics' is a capacious term that has come to denote, first, struggles over access to birth control, sexism and conservative family values - and, second, struggles over inequalities that the widespread, but uneven and often fraught, adoption of new reproductive technologies has tended to exacerbate. ${ }^{4}$ In the 1980 s and early 1990 s, as women's studies was forming as an academic field, feminist scholars increasingly turned their attention to the politics of motherhood, pregnancy and abortion. Faye Ginsburg and Rayna Rapp's landmark article, 'The Politics of Reproduction', consolidated the field

\footnotetext{
${ }^{1}$ Charles Barthold and Hervé Corvellec, “'For the Women”: In Memoriam Simone Veil (1927-2017)', Gender, Work \& Organization, 25, 6 (2018), 593-600.

${ }^{2}$ Science Museum Press Office, 'Science Museum Celebrates 40 Years of IVF With New Exhibition', 30 May 2018, https://www.sciencemuseum.org.uk/about-us/press-office/science-museum-celebrates-40-years-ivf-new-e xhibition, accessed 2 December 2018.

3 BBC News, 'Louise Brown: World's First IVF Baby's Family Archive Unveiled', 25 July 2018, https://www.b bc.co.uk/news/uk-england-bristol-44940929, accessed 2 December 2018.

${ }^{4}$ Mary O'Brien, The Politics of Reproduction (Toronto: York University, 1976); Hilary Homans (ed.), The Sexual Politics of Reproduction (Aldershot: Gower, 1985); Patricia Spallone, Beyond Conception: The New Politics of Reproduction (Basingstoke: Macmillan Education, 1989); Ken Arnold, Lesley Hall and Julia Sheppard, Birth and Breeding: The Politics of Reproduction in Modern Britain (London: Wellcome Trust, 1993); Faye D. Ginsburg and Rayna Rapp, Conceiving the New World Order: Global Politics of Reproduction (Berkeley: University of California Press, 1995); Rickie Solinger, Pregnancy and Power: A Short History of Reproductive Politics in America (New York: New York University Press, 2007); Isabelle Engeli, Les politiques de la reproduction: les politiques d'avortement et de procréation médicalement assistée en France et en Suisse [The politics of reproduction: the politics of abortion and medically assisted reproduction in France and Switzerland] (Paris: L'Harmattan, 2010); Solinger, Reproductive Politics: What Everyone Needs to Know (Oxford: Oxford University Press, 2013); Laura Briggs, How All Politics Became Reproductive Politics: From Welfare Reform to Foreclosure to Trump (Oakland: University of California Press, 2017).
} 
for anthropologists. ${ }^{5}$ Since then, an increasingly diverse range of researchers across the humanities and social sciences have explored how reproductive politics link scientific and medical knowledge - especially about women's reproductive bodies - to national and transnational political, legal, religious, colonial and postcolonial regimes of fertility regulation. ${ }^{6}$

Separated only by a narrow body of water, and historically entangled in various ways, France and Britain invite comparison; ${ }^{7}$ but, with the notable exception of Melanie Latham's Regulation Reproduction, histories of reproduction have for the most part been confined to the national level, and approaches have to some extent developed in isolation. While Latham's work provided the first in-depth study of the legal changes pertaining to contraception, abortion and assisted conception in Britain and France over the twentieth century, she focused mainly on the parliamentary systems of each country, neglecting the powerful role played by cultural shifts in bringing about these changes. ${ }^{8}$ As the contributions to this special issue show, doctors and activists not only influenced policymakers but also facilitated access to information, helping to establish a more favourable milieu for the public and political reception of radical ideas about reproduction.

While French officials have long feared population decline, their British counterparts were historically more concerned with the over-prolific poor. Birth control and abortion became increasingly acceptable in Britain in the mid-twentieth century, just as legal prohibitions and punishments became more severe in France. Religious tradition also played a key role in shaping different national policies. Namely, the Catholic Church opposed birth control France while Anglican bishops legitimised contraception in the 1930s. Beyond comparison, there were direct exchanges of information and ideas, including about contraception, eugenics and 'family planning', an initially British concept. Contraceptive devices, too, crossed the border, from Britain to France, while French women travelled to London to obtain abortions after Britain became one of the first

\footnotetext{
5 Faye Ginsburg and Rayna Rapp, 'The Politics of Reproduction', Annual Review of Anthropology, 20 (1991), 311-43. See also Rene Almeling, 'Reproduction', Annual Review of Sociology, 41 (2015), 423-42.

${ }^{6}$ On reproductive politics in colonial and postcolonial settings: Owen White, Children of the French Empire: Miscegenation and Colonial Society in French West Africa 1895-1960 (Oxford: Clarendon Press, 1999); Amy Kaler, Running After Pills: Politics, Gender, and Contraception in Colonial Zimbabwe (Portsmouth: Heinemann, 2003); Lynn M. Thomas, Politics of the Womb: Women, Reproduction, and the State in Kenya (Berkeley: University of California Press, 2003); Susanne M. Klausen, Race, Maternity, and the Politics of Birth Control in South Africa, 1910-39 (Basingstoke: Palgrave Macmillan, 2004); Sarah Hodges (ed.), Reproductive Health in India: History, Politics, Controversies (New Delhi: Orient Longman, 2006); Sanjam Ahluwalia, Reproductive Restraints: Birth Control in India, 1877-1947 (Urbana: University of Illinois Press, 2008); Hodges, Contraception, Colonialism and Commerce: Birth Control in South India, 1920-40 (Aldershot: Ashgate, 2008); Karl Ittmann, Dennis D. Cordell and Gregory H. Maddox (eds), The Demographics of Empire: The Colonial Order and the Creation of Knowledge (Columbus: Ohio University Press, 2010) Emmanuelle Saada, Empire's Children: Race, Filiation, and Citizenship in the French Colonies (Chicago: University of Chicago Press, 2012); Juanita De Barros, Reproducing the British Caribbean: Sex, Gender, and Population Politics after Slavery (Chapel Hill: University of North Carolina Press, 2014); Nicole C. Bourbonnais, Birth Control in the Decolonizing Caribbean: Reproductive Politics and Practice on Four Islands, 1930-70 (New York: Cambridge University Press, 2016); Philippa Levine, 'Imperial encounters', in Nick Hopwood, Rebecca Flemming and Lauren Kassell (eds), Reproduction: Antiquity to the Present Day (Cambridge: Cambridge University Press, 2018), 485-97.

${ }^{7}$ See, for example, Viviane Quirke and Jean-Paul Gaudillière, 'The Era of Biomedicine: Science, Medicine, and Public Health in Britain and France after the Second World War', Medical History, 52 (2008), 441-52.

${ }^{8}$ See Melanie Latham, Regulating Reproduction: A Century of Conflict in Britain and France (Manchester: Manchester University Press, 2002).
} 
Western countries to decriminalise abortion in 1968. France and Britain, thus, are strategic fields to study comparatively.

In addition to these divergent historical trajectories, the two nations have remarkably different historiographical traditions. Demography has long been strongly institutionalised in France, where a large number of demographic studies have been devoted to reproduction. ${ }^{9}$ In Britain, the history of medicine and oral history, combined with demographic analysis of Britain's dramatic 'fertility transition', have provided some of the most productive lines of inquiry. ${ }^{10}$ Media studies are beginning to make strides in both countries, generating new questions about the crucial developments in communications technology that produced mass audiences for often controversial information about all aspects of reproduction. ${ }^{11}$

Against a backdrop of national histories, this special issue adopts an explicitly comparative perspective. ${ }^{12}$ The period covered in this special issue, from around 1900 to the present, is one that witnessed major changes in reproductive politics. This is especially true of the decades after World War II, a significant and transformative period in the history of reproduction that saw the advent of 'the pill', the liberalisation of access to contraception and the decriminalisation of abortion in several Western countries, as well as the increasing medicalisation of pregnancy and childbirth, culminating in IVF.

Empirically grounded in medical, news media and activist sources, as well as ethnographic fieldwork, the article addresses questions of how information, practices and tools crossed national boundaries and circulated between groups of experts, activists and laypeople: Which arguments did campaigners put forward to advance their distinctive agendas? How did these arguments travel and how did they fare with policymakers and with the more general public? To what extent did changing scientific and medical knowledge shape reproductive politics? And, not least, what role did the media play?

\footnotetext{
${ }^{9}$ On the French tradition of historical demography, see, for example, Paul-André Rosental, L'intelligence démographique: sciences et politiques des populations en France, 1930-60 [Demographic intelligence: The science and politics of population in France, 1930-60] (Paris: Jacob, 2003); Rosental, 'The Novelty of an Old Genre: Louis Henry and the Founding of Historical Demography', Population, 58, 1 (2003), 97-130.

${ }^{10}$ Kate Fisher, Birth Control, Sex, and Marriage in Britain 1918-60 (Oxford: Oxford University Press, 2006); Simon Szreter, Fertility, Class and Gender in Britain, 1860-1940 (Cambridge: Cambridge University Press, 2002); Szreter and Kate Fisher, Sex Before the Sexual Revolution, Intimate Life in England, 1918-63 (Cambridge: Cambridge University Press, 2010).

${ }^{11}$ Roy Porter and Lesley Hall, The Facts of Life: The Creation of Sexual Knowledge in Britain, 1650-1950 (New Haven: Yale University Press, 1995); Lutz D.H. Sauerteig and Roger Davidson (eds), Shaping Sexual Knowledge: A Cultural History of Sex Education in Twentieth-Century Europe (London: Routledge, 2009); Manon Parry, Broadcasting Birth Control: Mass Media and Family Planning (New Brunswick: Rutgers University Press, 2013); Christian Bonah and Anja Laukötter (eds), 'Screening Diseases: Films on Sex Hygiene in Germany and France in the first half of the 20th Century', a special issue of Gesnerus, 72, 1 (2015); Nick Hopwood, Peter Murray Jones, Lauren Kassell and Jim Secord (eds), 'Communicating Reproduction', a special issue of Bulletin of the History of Medicine, 89, 3 (2015); Jesse Olszynko-Gryn and Patrick Ellis (eds), a special issue of 'Reproduction on Film', British Journal for the History of Science, 50, 3 (2017).

12 For recent examples of the comparative approach to reproduction: Caroline Rusterholz, 'Reproductive Behaviour and Contraceptive Practices in Comparative Perspective, Switzerland (1955-70)', The History of the Family, 20 (2015), 41-68; Rusterholz, Deux enfants c'est déjà pas mal. Famille et fécondité en Suisse (195570) [Two children is not too bad. Family and fertility in Switzerland (1955-70)] (Lausanne: Antipodes, 2017); Yuliya Hilevych and Caroline Rusterholz, "'Two Children to Make Ends Meet”: The Ideal Family Size, Parental Responsibilities and Costs of Children on Two Sides of the Iron Curtain During the Post-War Fertility Decline', History of the Family, 23, 3 (2018), 408-25; Rusterholz, 'Religion and contraceptive in comparative perspective: Switzerland, 1950-70', in Alana Harris (ed.), The Schism of '68: Catholicism, Contraception and 'Humanae Vitae' in Europe, 1945-75 (Cham: Palgrave Macmillan, 2018), 99-119.
} 
The rest of this introductory article sketches a cross-channel history of reproductive politics in the two countries and presents the five articles that constitute the special issue.

\section{From Malthus to Pronatalism}

Histories of population science and politics suggest that France and Britain had different fears regarding the state of their population; pronatalism was central in France while neoMalthusian and eugenic concerns predominated in Britain. Despite these main differences, some experts in France and Britain shared neo-Malthusian and eugenic concerns at the turn of the twentieth century. First published anonymously in London in 1798, Thomas Robert Malthus's Essay on the Principle of Population argued that population growth, especially among the poor, would outstrip available resources unless kept in check by 'moral restraint'. ${ }^{13}$ At around the same time - much earlier than any other European country - France began a steady fertility decline that reached its lowest point in the mid-1930s. ${ }^{14}$ Initially framed as 'degeneration' and somewhat later as 'depopulation', this downward trend was a major source of concern for medical doctors, population experts, politicians and religious leaders in France. ${ }^{15}$ Abortion later became a source of major concern in both countries, but for somewhat different reasons: depopulation in France; maternal mortality in Britain. The trend towards criminalisation, however, began in the early 1800 s.

Founded in London in 1877, the Malthusian League promoted the education of individuals in sexual matters and contraceptive use with the aim of poverty reduction. In 1913, the League began publishing leaflets with Hygienic Methods of Family Limitation, the first medical birth control publication of the twentieth century that reviewed existing techniques of birth control. ${ }^{16}$ Neo-Malthusianism also made gains in France, where Paul Robin, an educator and scientist, promoted the movement upon his return from exile in London. ${ }^{17}$ In 1900, he initiated a series of international conferences and established an International Federation of Neo-Malthusian Leagues (Fédération universelle de la régénération humaine). ${ }^{18}$ As with America's Comstock Laws of $1873,{ }^{19}$ the French law of 1898 on pornography prohibited the transmission of immoral information and included

13 Angus McLaren, A History of Contraception from Antiquity to the Present Day (Oxford: Blackwell, 1990), 181-2; Alison Bashford, Global Population: History, Geopolitics, and Life on Earth (New York: Columbia University Press 2014); Bashford and Joyce E. Chaplin (eds), The New Worlds of Thomas Robert Malthus: Rereading the Principles of Population (Princeton: Princeton University Press, 2016); Lesley Hall, 'Movements to separate sex and reproduction', in Hopwood et al., op. cit. (note 6), 427-41.

14 The French concern with population loss, though not grounded in demographic reality, began even earlier: Carol Blum, Population, Reproduction, and Power in Eighteenth-Century France (Johns Hopkins University Press, 2002).

${ }^{15}$ Francis Ronsin, La grève des ventres: propagande néo-malthusienne et baisse de la natalité française, XIXe$X X e$ siècles [The bellies strike: neo-Malthusian propaganda and the decline in the French birth rate, 19th20th centuries] (Paris: Aubier Montaigne, 1980); Marie-Monique Huss, 'Pronatalism in the Inter-War Period in France', Journal of Contemporary History, 25, 1 (1990), 39-68; Andres Horacio Reggiani, 'Procreating France: The Politics of Demography, 1919-45', French Historical Studies, 19, 3 (1996), 725-54; Virginie De Luca Barrusse and Harriet Coleman, 'The "Denatality Complex": The Demographic Argument in the Birth Control Debate in France, 1956-67', Population, 73, 1 (2018), 9-32.

${ }^{16}$ Rosanna Ledbetter, A History of the Malthusian League, 1877-1927 (Columbus: Ohio State University Press, 1986).

${ }^{17}$ Angus McLaren, Sexuality and Social Order: The Debate over the Fertility of Women and Workers in France, 1770-1920 (New York: Holmes \& Meier, 1983), 93-109.

${ }^{18}$ Ledbetter, op. cit. (note 16); Hall, op. cit. (note 13).

${ }^{19}$ Andrea Tone, Devices and Desires: A History of Contraceptives in America (New York: Macmillan, 2001). 
contraception in its list of 'unlawful products'.$^{20}$ But the sale and public advertisement of contraceptive devices was not explicitly made illegal until 1920, so (neo-Malthusian) campaigners were able to distribute information on birth control and contraceptive devices in France. ${ }^{21}$

Eugenics was a transnational movement that found support across the political spectrum. ${ }^{22}$ A British innovation, the term itself was coined by Charles Darwin's cousin, Francis Galton, in 1883 to encompassed the notion that the 'unfit' poor were multiplying while the 'fit' middle- and upper-classes were dying out. ${ }^{23}$ Debates over population often conflated quality and quantity, as prominent figures on both sides of the channel were greatly influenced by Galton's eugenics. ${ }^{24}$ For example, early twentieth-century 'integral' or 'individualist' feminists - who 'sought equality of opportunity for the individual, irrespective of sex, familial considerations, or national concern' - and neo-Malthusians both drew on eugenic arguments about population quality and on the idea of birth control. ${ }^{25}$ In contrast to their counterparts in Britain, French neo-Malthusians placed 'women and women's control over their own bodies at the centre of birth control doctrine' ${ }^{26}$ Robin's discipline, Nelly Roussel, explicitly connected women's political citizenship with the fact that female emancipation lay in birth control. She, other neo-Malthusians and 'integral' feminists increasingly faced opposition from 'relational' feminists - who contrastingly sought 'equality in difference' - and other pronatalists, who sanctified motherhood as a patriotic duty and supported a gendered division of labour in both society and the family. ${ }^{27}$

In Britain, a focus on population size and quality led commentators to set up the National Birth Rate Commission in 1912 to investigate the reasons behind differential

${ }^{20}$ Latham, op. cit. (note 8).

${ }^{21}$ Ronsin, op. cit. (note 15).

22 Alison Bashford and Philippa Levine (eds), The Oxford Handbook of the History of Eugenics (Oxford: Oxford University Press, 2010); Dagmar Herzog, Unlearning Eugenics: Sexuality, Reproduction, and Disability in PostNazi Europe (Madison: University of Wisconsin Press, 2018).

${ }^{23}$ Pauline M.H. Mazumdar, Eugenics, Human Genetics, and Human Failings: The Eugenics Society, its Sources and its Critics in Britain (London: Routledge, 1992); Diane B. Paul, Controlling Human Heredity: 1896 to the Present (Amherst: Humanity Books, 1995).

${ }^{24}$ William H. Schneider, Quality and Quantity: The Quest for Biological Regeneration in Twentieth-Century France (Cambridge: Cambridge University Press, 1990); Richard Soloway, Demography and Degeneration: Eugenics and the Declining Birthrate in Twentieth Century Britain (Chapel Hill: University of North Carolina Press, 1990); Alain Drouard, 'Aux origines de l'eugénisme en France: Le néo-Malthusianisme (1896-1914)' [Origins of eugenics in France: Neo-Malthusianism (1896-1914)], Population, 47 (1992), 435-59; Anne Carol, L'eugénisme en France. Les médecins face à la procréation [Eugenics in France: medicine confronts procreation] (Paris: Flammarion, 1995); Lucy Bland and Lesley A. Hall, 'Eugenics in Britain: the view from the metropole', in Bashford and Levine (eds), op. cit. (note 22), 213-27; Richard S. Fogarty and Michael A. Osborne, 'Eugenics in France and the colonies', in Bashford and Levine (eds), op. cit. (note 22), 332-46; Paul-André Rosental, Destins de l'eugénisme [Eugenic destiny] (Paris: Seuil, 2016).

${ }^{25}$ Karen Offen, 'Depopulation, Nationalism, and Feminism in fin-de-siècle France', American Historical Review, 89, 3 (1984), 648-76; 654.

${ }^{26}$ Elinor Accampo, Blessed Motherhood, Bitter Fruit: Nelly Roussel and the Politics of Female Pain in Third Republic France (Baltimore: Johns Hopkins University Press, 2006), 5.

27 Offen, op. cit. (note 25); Accampo, op. cit. (note 26). See also Elinor Accampo, 'The Gendered Nature of Contraception in France: Neo-Malthusianism, 1900-20', Journal of Interdisciplinary History, 34, 2 (2003), 235-62; Anne Cova, Féminismes et néo-malthusianismes sous la III République: 'La liberté de la maternité' [Feminism and neo-Mathusianism during the Third Republic: 'The freedom of motherhood'] (Paris: L'Harmattan, 2011). 
fertility. Others proposed remedies for 'race suicide' by targeting women. ${ }^{28}$ Workingclass mothers in particular came under increased surveillance by the state and private charities regarding the welfare of their children. For instance, 'social hygienists' - middleclass reformers working in voluntary organisations - promoted education in 'mothercraft', gave information to individuals on the risks of venereal disease (VD) and discouraged sexual relations except between husband and wife. They supported the Maternal and Child Welfare Act 1918 because they perceived environmental conditions as essential factors in infant mortality, and it aimed to improve access to welfare clinics, day nurseries and health visitors in England and Wales. ${ }^{29}$

Even as support for birth control remained a radical position well into the twentieth century, national campaigns against VD - aimed at soldiers and unmarried men - raised the profile of condoms, officially used for prophylaxis only, during the Great War. ${ }^{30}$ Manufacturers in Germany, Britain and the United States came to dominate a lucrative international market. ${ }^{31}$ Meanwhile in the United States, Margaret Sanger, the American nurse and radical feminist who coined the term 'birth control', was arrested for opening the nation's first birth control clinic in Brooklyn in $1916 .{ }^{32}$ Sanger had previously evaded arrest under the Comstock Laws by fleeing to London, where she came into contact with the Malthusian League and met the British scientist Marie Stopes, who was writing Married Love, the landmark book that influentially positioned contraception as respectable for the middle classes. ${ }^{33}$

In France, a pronatalist movement reacted to both the fall in birth rate and the rise of neo-Malthusianism. Founded in 1896 and 1911, respectively, the anti-Malthusian Alliance nationale pour l'accroissement de la population française (National alliance for French population growth) and Le Groupe parlementaire pour la protection de la famille nombreuse (Parliamentary group for the production of large families) aimed to raise public awareness around the demographic deficit that threatened France's military power and sought to encourage large families by lobbying for social benefits. ${ }^{34}$ In the name of social hygiene, the French government also launched and supported public campaigns on the scourge of VD. ${ }^{35}$

${ }^{28}$ Anne Davin, 'Imperialism and Motherhood', History Workshop, 5, 1 (1978), 9-65.

29 Soloway, op. cit. (note 24).

${ }^{30}$ Anne Hanley, Medicine, Knowledge and Venereal Diseases in England, 1886-1916 (Cham: Palgrave Macmillan, 2017).

${ }^{31}$ Claire L. Jones, "Under the Covers?" Commerce, Contraceptives and Consumers in England and Wales, 1880-1960', Social History of Medicine, 29, 4 (2016), 734-56; Ben Mechen, “'Closer together”: Durex condoms and contraceptive consumerism in 1970s Britain', in Jennifer Evans and Ciara Meehan (eds), Perceptions of Pregnancy from the Seventeenth to the Twentieth Century (Cham: Palgrave Macmillan, 2017), 213-36; Jesse Olszynko-Gryn, 'Technologies of contraception and abortion', in Hopwood et al., op. cit. (note 6), 535-51.

32 Ellen Chesler, Woman of Valor: Margaret Sanger and the Birth Control Movement in America (New York: Simon \& Schuster, 2007).

33 Alexander C.T. Geppert, 'Divine Sex, Happy Marriage, Regenerated Nation: Marie Stopes's Marital Manual Married Love, and the Making of a Best Seller, 1918-55', Journal of the History of Sexuality, 8, 3 (1998), 389-433.

${ }^{34}$ Fabrice Cahen, Gouverner les moeurs. La lutte contre l'avortement en France, 1890-1950 [Governing mores. The struggle against abortion in France, 1890-1950] (Paris: INED, 2016). See also, Virginie De Luca Barrusse, Les familles nombreuses: une question démographique, un enjeu politiue. France (1880-1940) [Large families: A demographic question, a political issue (France, 1880-1940)], (Rennes: Presses universitaires de Rennes, 2008). 35 Virginie De Luca Barrusse, 'Natalisme et hygiénisme en France de 1900 à 1940. L'exemple de la lutte antivénérienne', [Pronatalism and social hygiene in France, 1900-40. The fight against venereal disease] Population, 64, 3 (2009), 531-60. 


\section{Interwar Divergence}

French and British reproductive politics increasingly diverged between the wars. Marie Stopes launched the Society for Constructive Birth Control and Racial Progress and opened Britain's first birth control clinic in London in $1921 .{ }^{36}$ The nationwide network of clinics maintained by Stopes and others promoted the pessary or cervical cap. ${ }^{37}$ Scientists, meanwhile, searched for the 'ideal' contraceptive. ${ }^{38}$ But working-class women especially tended to reject 'modern' female methods, instead preferring to rely on the 'traditional' male method of withdrawal, or coitus interruptus. ${ }^{39}$ Women also used the periodic abstinence and supported a huge market in 'female pills', abortifacients of dubious efficacy euphemistically advertised as patent treatments for 'irregularities'. ${ }^{40}$

Eugenic concerns gained ground in the 1920s and 1930s and fed into various campaigns and public health initiatives. A British campaign for voluntary sterilisation failed to gain traction, but 'reform' eugenicists had more success with 'positive' measures such as encouraging middle-class women to procreate. Health reformers, including the London obstetrician and 'natural childbirth' advocate Grantly Dick-Read, worried about the high rate of maternal mortality. They blamed excessive technological interventions and the differential birth rate, and argued that education (instead of intervention) and a 'return' to naturally painless delivery would reduce the morbidity rate and encourage the right sort of reproduction. ${ }^{41}$

Following the devastating military losses of World War I, the French fear of population decline intensified; propagandists redoubled their efforts to represent contraception and abortion as a demographic threat. ${ }^{42}$ In 1920 , the French state, aided by national population experts, enacted a 'strongly pronatalist population policy that sought to encourage fertility through a combination of positive programs that enhanced couples' ability to care for children' and 'repressive programs that limited couples' access to contraception

${ }^{36}$ Hall, op. cit. (note 13).

${ }^{37}$ Deborah Cohen, 'Private Lives in Public Spaces: Marie Stopes, the Mothers' Clinics and the Practice of Contraception', History Workshop Journal, 35, 1 (1993), 95-116; Peter Neushul, 'Marie C. Stopes and the Popularization of Birth Control Technology', Technology and Culture, 39, 2 (1998), 245-72; Clare Debenham, Birth Control and the Rights of Women: Post-Suffrage Feminism in the Early Twentieth Century (London: IB Tauris, 2014).

${ }^{38}$ Richard A. Soloway, 'The "Perfect Contraceptive": Eugenics and Birth Control Research in Britain and America in the Interwar Years', Journal of Contemporary History, 30, 4 (1995), 637-64; Lara V. Marks, Sexual Chemistry: A History of the Contraceptive Pill (New Haven: Yale University Press, 2010); Ilana Löwy, "Sexual Chemistry" Before the Pill: Science, Industry and Chemical Contraceptives, 1920-60', British Journal for the History of Science, 44, 2 (2011), 245-74; Caroline Rusterholz, 'Testing the Gräfenberg Ring in Interwar Britain: Norman Haire, Helena Wright, and the Debate Over Statistical Evidence, Side Effects, and Intra-Uterine Contraception', Journal of the History of Medicine and Allied Sciences, 72, 4 (2017), 448-67; Natasha Szuhan, 'Sex in the Laboratory: The Family Planning Association and Contraceptive Science in Britain, 1929-59', British Journal of History of Science in Britain, 51, 3 (2018), 487-510.

${ }^{39}$ Kate Fisher, op. cit. (note 10).

40 Jeffrey Weeks, Sex, Politics and Society: The Regulation of Sexuality since 1800, 3rd edn (Abingdon: Routledge, 2013), 87; Olszynko-Gryn, op. cit. (note 31).

${ }^{41}$ Ornella Moscucci, 'Holistic Obstetrics: The Origins of "Natural Childbirth" in Britain', Postgraduate Medical Journal, 79, 929 (2003), 168-73. On postwar developments: Salim Al-Gailani, 'Drawing Back the Curtain: Natural Childbirth on Screen in 1950s Britain', British Journal for the History of Science 50, 3 (2017), 473-93; Paula A. Michaels, 'Comrades in the Labor Room: The Lamaze Method of Childbirth Preparation and France's Cold War Home Front, 1951-57', American Historical Review, 115, 4 (2010), 1031-60; Michaels, Lamaze: An International History (Oxford: Oxford University Press, 2014).

42 Fabrice Cahen, 'De l'efficacité des politiques publiques. La lutte contre l'avortement 'criminel' en France, 1890-1950' [The effectiveness of public policies. The fight against 'criminal' abortion in France, 1890-1950]', Revue d'histoire moderne et contemporaine, 58 (2011), 90-117. 
and abortion'. ${ }^{43}$ The 1920 law explicitly forbade the sale, distribution and advertising of contraceptive devices, punishable by fines and imprisonment, as well as the inducement to abortion. At the same time, the government created a Conseil supérieur de la natalité (Birthrate committee), and tasked it with taking any measures necessary to increase national fecundity and support large families. Three years later, a new law transferred abortion cases from the Cours d'Assises (crimes) to Tribunaux correctionnels (offences) and set jail terms for both abortionists and their clients. ${ }^{44}$

These divergent stances on birth control were not limited to the legal and political spheres, but extended to the religious domain as well. In 1930, Britain's birth control clinics united to become the National Birth Control Council (NBCC), and the Lambeth Conference of the Anglican Church officially allowed contraception within marriage. This marked a radical break from the past and from the Catholic Church. ${ }^{45}$ The following year, the NBCC changed its name to the National Birth Control Association (NBCA) and the publication of Pope Pius XI's encyclical, Casti Connubi, reinforced the prohibition against contraception in marriage, forcing Catholics in France to navigate between doctrine, on the one hand, and economic and other mundane constraints on family size, on the other. Testifying to these concerns, many anxious married couples sent imploring letters to Father Jean Viollet, a renowned Catholic expert in sexual matters and founding member in 1918 of l'Association du mariage chrétien (Association of Christian Marriage), which taught premarital abstinence and fecundity in marriage. ${ }^{46}$

Just as birth control was becoming almost conventional in Britain, ${ }^{47}$ pronatalism began to form the political centre-ground of interwar France, attracting supporters from the right and left, and from all segments of the society. ${ }^{48}$ The French government began introducing family allowances, and insurance companies linked the payment of maternity benefits to antenatal and postpartum check-ups as well as regular visits by social workers. ${ }^{49}$ This process reached its climax with the creation of a Haut comité de la population (High committee on population) in 1939, a few weeks before France entered World War II. From then on the French state would be continually involved in previously private aspects of reproductive life. ${ }^{50}$

Campaigns and public discourse in 1930s Britain tended to revolve around the perceived rise in illegal abortion and, relatedly, maternal mortality - trends that were attributed to the deepening economic crisis following the stock market crash of 1929. Feminists founded the Abortion Law Reform Association (ALRA) in 1936, ${ }^{51}$ and the National

${ }^{43}$ Dennis Hodgson, 'Abortion, Family Planning, and Population Policy: Prospects for the Common-Ground Approach', Population and Development Review, 35, 3 (2009), 479-518, 493.

${ }^{44}$ Cahen, op. cit. (note 34).

45 Richard Soloway, Birth Control and the Population Question in England 1877-1930 (Chapel Hill: University of North Carolina Press, 1982), 233-55.

${ }^{46}$ Martine Sevegrand, 'Limiter les naissances. Le cas de conscience des catholiques français (1880-1939)' [Limiting births. The case of French Catholics' conscience (1880-1939)], Vingtième Siècle, Revue d'Histoire, 30 (1991), 40-54; Sevegrand, L'amour en toutes lettres. Questions à l'abbé Viollet sur la sexualité (1924-43) [Love in letters. Questions to Father Viollet on sexuality (1924-43)] (Paris: Albin Michel, 1996).

${ }^{47}$ Hall, op. cit. (note 13).

${ }^{48}$ Huss, op. cit. (note 15).

${ }^{49}$ Reggiani, op. cit. (note 15).

${ }^{50}$ Reggiani, op. cit. (note 15), 731.

51 Barbara Brookes, Abortion in England, 1900-67 (London: Croom Helm, 1988); Stephen Brooke, “A New World for Women"? Abortion Law Reform in Britain During the 1930s', American Historical Review, 106, 2 (2001), 431-59; Emma L. Jones, 'Attitudes to Abortion in the Era of Reform: Evidence from the Abortion Law Reform Association Correspondence', Women's History Review, 20, 2 (2011), 283-98. 
Council of Women demanded a government inquiry into abortion. In 1937 the Ministry of Health published a report on maternal mortality and, together with the Home Office, set up the interdepartmental 'Birkett' committee on abortion. ${ }^{52}$ Meanwhile, the landmark Rex v. Bourne case of 1938 liberalised abortion law in England and Wales. Aleck Bourne, a prominent gynaecologist, went public with the technically illegal operation he had performed - under modern hospital conditions, the press contrasted, to those of the 'backstreet' abortionist - on a young girl who had been raped by soldiers. Whereas the Infant Life (Preservation) Act 1929 had allowed the child to be sacrificed if the mother's life was at stake, the 1938 ruling broadened the criterion to include her physical and mental wellbeing. 53

In 1939, on the eve of World War II, the Birkett committee published its final report and the NBCA was decisively renamed the Family Planning Association (FPA) ${ }^{54}$ By then, pregnancy testing, a German innovation of the late 1920s, had become institutionalised in Britain; a 'pregnancy diagnosis station' in Edinburgh performed thousands of tests every year for doctors around the country. ${ }^{55}$ Across the channel, the Family Code established a comprehensive system of state support and incentives for families, such as a birth premium for the first child born within two years of a marriage, mainly implemented, under the German occupation, by the Vichy government headed by Marshal Philippe Pétain. Moving in the opposite direction of Rex $v$. Bourne, abortion became a crime against the state, on a par with treason, in 1942. The following year saw the execution of Marie-Louise Giraud, a faiseuse d'anges (literally, 'angel maker', or lay abortionist) and one of the last women to be guillotined in France. ${ }^{56}$

As Fabrice Cahen shows in this issue, medical experts and politicians broadly agreed on the need for pregnancy notification in France in the 1930s and 1940s. But they rejected pregnancy testing on the grounds that it could be abused by women planning to seek out illegal abortion. Extending Jesse Olszynko-Gryn's research on pregnancy testing in Britain, Cahen tells a strikingly different story about France. Whereas the British state adopted a laissez-faire attitude and turned a blind eye towards the possible connection between pregnancy testing and illegal abortion, ${ }^{57}$ the French state actively persecuted diagnostic laboratories. However, in both countries a similar feature is noticeable - namely,

\footnotetext{
52 Jane Lewis, The Politics of Motherhood: Child and Maternal Welfare in England, 1900-39 (London: Croom Helm, 1980), 209; Stephen Brooke, Sexual Politics: Sexuality, Family Planning, and the British Left from the 1880 s to the Present Day (Oxford: Oxford University Press, 2011), 95.

53 John Keown, Abortion, Doctors and the Law: Some Aspects of the Legal Regulation of Abortion in England from 1803 to 1982 (Cambridge: Cambridge University Press, 1988); Barbara Brookes and Paul Roth, 'Rex v. Bourne and the medicalization of abortion', in Michael Clark and Catherine Crawford (eds), Legal Medicine in History (Cambridge: Cambridge University Press, 1994), 314-43; Sally Sheldon, Beyond Control: Medical Power and Abortion Law (London: Pluto, 1997).

54 Audrey Leathard, The Fight for Family Planning: Development of Family Planning Service in Britain, 192174 (London: Macmillan, 1980).

55 Jesse Olszynko-Gryn, 'The Demand for Pregnancy Testing: The Aschheim-Zondek Reaction, Diagnostic Versatility, and Laboratory Services in 1930s Britain', Studies in the History and Philosophy of Biological and Biomedical Sciences, 47 (2014), 233-47.

56 Cahen, op. cit. (note 34). The story of Giraud was dramatised in the 1988 film, Une affaire de femmes (Story of women), directed by Claude Chabrol and staring Isabelle Huppert; see Rosemarie Scullion, 'Family Fictions and Reproductive Realities in Vichy France: Claude Chabrol's Une Affaire de femmes', Esprit Créateur, 33, 1 (1993), 85-103.

57 Jesse Olszynko-Gryn, 'Pregnancy Testing in Britain, c. 1900-67: Laboratories, Animals and Demand from Doctors, Patients and Consumers' (unpublished PhD thesis, University of Cambridge, 2014), 131-49.
} 
the active role of doctors who attempted to forge alliances with politicians and other elites to shape reproductive policy and practice and to disseminate information.

At around the same time, the more relaxed legal situation in Britain allowed medical experts to circulate knowledge of birth control. As Caroline Rusterholz explains in this issue, British female doctors were key agents in a process of medicalisation by making contraceptive devices and information available to lay women. They produced medical information about birth control and spread this knowledge via birth control manuals and articles. Not only were British medical women active and experienced agents in the familyplanning movement, they also represented a conduit of information and training crucial for French doctors. Thanks to their efforts, contraceptive information travelled from Britain to France, where it laid the foundation for the French family planning movement.

\section{Fights for Contraception and Abortion}

After World War II, female doctors in Britain actively campaigned to re-establish an international movement of 'planned parenthood', favouring transnational exchange between countries. ${ }^{58}$ The newly created National Health Service (NHS) kept birth control at arm's length, but private clinics proliferated and gained respectability in 1955, when Conservative Health Minister Iain Macleod made a show of visiting one of them in recognition of the FPA's Silver Jubilee. ${ }^{59}$ Meanwhile, the rising incidence of premarital intercourse - or at least increasing recognition thereof - intensified old anxieties around illegitimacy. ${ }^{60}$ Access to contraception and abortion extended in the 1960 s and 1970s, largely thanks to feminist activism in collaboration with sympathetic doctors and the liberal welfare state; the first Brook Advisory Centre began providing contraception and advice to unmarried minors in $1964 .{ }^{61}$

Part of a trend that also decriminalised homosexuality and reformed divorce law, ${ }^{62}$ the Abortion Act 1967 liberalised access to abortion in Britain, but in such a way that it made individual doctors into gatekeepers with considerable discretion in how they interpreted the law. ${ }^{63}$ Access to NHS services remained geographically patchy, so charities in London and Birmingham established a compensatory network of non-profit abortion clinics, with the latter developing into the British Pregnancy Advisory Service (BPAS) ${ }^{64}$ Thousands of women seeking abortion travelled to Britain from France, Ireland and other countries in Europe and the Commonwealth, where abortion was still a crime. ${ }^{65}$ Alongside other

\footnotetext{
${ }^{58}$ Rusterholz, this issue.

${ }^{59}$ Leathard, op. cit. (note 54), 224.

${ }^{60}$ Carole Dyhouse, Girl Trouble: Panic and Progress in the History of Young Women (London: Zed, 2013). See also Lesley A. Hall, Sex, Gender and Social Change in Britain since 1880, 2nd edn (Basingstoke: Palgrave Macmillan, 2012); Weeks, op. cit. (note 40).

${ }^{61}$ Hera Cook, The Long Sexual Revolution: English Women, Sex, and Contraception 1800-75 (Oxford: Oxford University Press, 2004), 288.

62 Weeks, op. cit. (note 40).

63 Sally Sheldon, Gayle Davis, Jane O’Neill and Clare Parker, 'The Abortion Act (1967): A Biography', Legal Studies (2018), 1-18, doi:10.1017/lst.2018.28. On abortion law reform in Scotland: Gayle Davis and Roger Davidson, "A Fifth Freedom" or "Hideous Atheistic Expediency”? The Medical Community and Abortion Law Reform in Scotland, c. 1960-75', Medical History, 50, 1 (2006), 29-48.

64 David Paintin, Abortion Law Reform in Britain 1964-2003: A Personal Account by David Paintin (Stratford: BPAS, 2015), 66-74.

65 Ann Rossiter, Ireland's Hidden Diaspora: The 'Abortion Trail' and the Making of a London-Irish Underground, 1980-2000 (London: IASC, 2009); Christabelle Sethna, 'From Heathrow Airport to Harley Street: the ALRA and the travel of nonresident women for abortion services in Britain', in Sethna and Gayle Davis
} 
scandals, such as aborted fetuses allegedly being made into soap, ${ }^{66}$ abortion 'tourism' fuelled a Christian conservative backlash against the Act. The formation of the Society for the Protection of the Unborn Child (SPUC) in 1967 and splinter group LIFE in 1970, in turn redirected feminist campaigns towards reproductive rights under the NHS. ${ }^{67}$

Activists in the newly formed women's liberation movement (WLM) demanded 'free contraception and abortion on demand' and organised drop-in services that combined free or at-cost pregnancy testing with sympathetic counselling, birth control advice and medical referrals, including to BPAS. ${ }^{6}$ Contraception was made freely available to unmarried women in 1974, when the network of clinics maintained by the FPA was absorbed into the NHS. ${ }^{69}$ But abortion became 'almost the definitive issue' of the WLM, with massive demonstrations against the anti-abortion bills of James White (1975) and John Corrie (1979), among others. ${ }^{70}$

In postwar France, Simone de Beauvoir influentially attributed women's oppression to biological reproduction in her classic book, The Second Sex (1949). ${ }^{71}$ And the 'Bac affair', which played out in public in spectacular fashion in 1954, finally turned the tide in favour of the progressive push for access to birth control information. A young couple accused of accidental manslaughter following the death of their fifth child were sentenced to seven years of imprisonment; but the trial revealed an exhausted wife who, after five consecutive pregnancies, could no longer look after her children. The Bacs were freed in 1956 after the testimonies of many expert witnesses defended the accused and underscored that such cases were unknown in Britain, where married adults enjoyed legal access to contraceptives and information about them. Contraception, they forcefully claimed, was a means to better family life. Among the doctors who defended the accused was gynaecologist Marie-Andrée Lagroua Weill-Hallé, a founding member of Maternité Heureuse (Happy Motherhood). ${ }^{72}$

Maternité Heureuse was established in 1956 as a private organisation by women and doctors from the upper middle classes of French society. As French popular opinion shifted in the 1950s, it increasingly attracted public support and favourable media coverage. ${ }^{73}$ Its aim was to disseminate contraceptive information to curb illegal abortion. In 1960, Maternité Heureuse became the Mouvement français pour le 'planning' familial (French Movement for Family Planning), self-consciously appropriating the English term that had come into fashion in earlier decades. ${ }^{74}$ The first French 'family planning' clinic

(eds), Abortion across Borders: Transnational Travel and Access to Abortion Services (Baltimore: Johns Hopkins University Press, 2019), 46-71.

66 Sheldon et al., op. cit. (note 53).

67 Alan Clarke, 'Moral Reform and the Anti-Abortion Movement', Sociological Review, 35 (1987), 123-49.

68 Jesse Olszynko-Gryn, 'The Feminist Appropriation of Pregnancy Testing in 1970s Britain', Women's History Review, Epub ahead of print: 11 July 2017, doi.org/10.1080/09612025.2017.1346869.

69 The final report of the Lane Committee, which had been charged with investigating the 1967 Act, upheld it unaltered in 1974: Ashley Wivel, 'Abortion Policy and the Politics on the Lane Committee of Enquiry, 1971-74', Social History of Medicine, 11, 1 (1998), 109-35.

70 Joni Lovenduski and Vicky Randall, Contemporary Feminist Politics: Women and Power in Britain (Oxford: Oxford University Press 1993).

${ }^{71}$ Sarah Franklin, 'Feminism and reproduction', in Hopwood et al., op. cit. (note 6), 627-39.

72 Bibia Pavard, Si je veux, quand je veux. Contraception et avortement dans la société française (1956-79) [If I want, when I want: contraception and abortion in France (1956-79)] (Rennes: Presses universitaires de Rennes, 2012); Sandrine Garcia, Mères sous influence: De la cause des femmes à la cause des enfants [Mothers under the influence: From a woman's cause to a child's cause] (Paris: Découverte, 2011).

${ }^{73}$ Pavard, this issue.

${ }^{74}$ Pavard, this issue; Rusterholz, this issue. 
opened in 1961 in Grenoble and was quickly followed by many others around the country. Campaigning by Maternité Heureuse led to the 'loi Neuwirth' in 1967. Named after the Gaullist politician, Lucien Neuwirth, who proposed it, the Neuwirth law finally overturned the 1920 ban on contraception.

Bibia Pavard's article in this issue interrogates grassroots activism to reassess the liberalisation of contraception in postwar France. Pavard demonstrates that old pronatalist arguments persisted well after the creation of Maternité Heureuse. She examines government and feminist archival records as well as extensive media coverage to show how activists challenged the legal prohibition against circulating information about contraception without questioning the all-important pronatalist imperative. After 'May 1968 ', the recently commemorated period of social upheaval in France, ${ }^{75}$ the flow of information about contraception became the focus of a power struggle between sexologists, feminists and leftwing activists. Pavard's study illustrates the imperative to take seriously communication as constitutive of reproductive politics and to challenge the dominant periodisation of French demographic discourse.

Feminists in France likewise campaigned for reproductive rights in the $1970 \mathrm{~s},{ }^{76}$ framing free contraception and abortion as 'a tool to overcome patriarchy' ${ }^{77}$ On 5 April 1971, the prominent weekly news magazine Nouvel Observateur (New Observer) published the manifeste des 343 (Manifesto of the 343), a sensational petition signed by 343 women who admitted to having had an illegal abortion. Written by de Beauvoir and signed by icons such as Catherine Deneuve, it was a major coup that forced the government's hand. ${ }^{78}$ Emboldened by the state's failure to prosecute any of the signatories, feminists established Choisir (Choice) and the Mouvement pour la libération de l'avortement et de la contraception (Movement for the Liberation of Abortion and Contraception). MLAC opened a centre in Paris in 1973, where doctors and nurses performed free illegal abortions, and it illegally distributed the banned 'militant' abortion film, Histoires d'A (1973). ${ }^{79}$ Abortion was debated at all levels of French society and the abortion bill drafted by Simone Veil, the new minister of health, passed for a trial period of five years in 1975. The 'loi Veil' legalised abortion in France. ${ }^{80}$

75 Bibia Pavard, Mai 68 (Paris: Presses universitaires de France, 2018).

${ }^{76}$ Bibia Pavard, Florence Rochefort and Michelle Zancarini-Fournel, Les lois Veil: Contraception 1974, IVG 1975 [The Veil's laws: Contraception 1974, Abortion 1975] (Paris: Armand Colin, 2012).

${ }^{77}$ Pavard, this issue. In French overseas territories, women of colour were forced to abort and coerced into sterilisation; few metropolitan feminists took notice. See Françoise Vergès, Le ventre des femmes: capitalisme, racialisation, féminisme [Women's womb: capitalism, racialization, feminism] (Paris: Albin Michel, 2017); Vèrges, 'On Women and their Wombs: Capitalism, Racialization, Feminism', Critical Times, 1, 1 (2018), $263-67$.

78 Two landmark abortion trials in 1972, in the Paris suburb of Bobigny, also helped to bring feminist discourse into the mainstream: Jennifer L. Sweatman, “It is not your personal concern": challenging expertise in the campaign to legalize abortion in France', in Shannon Stettner, Katrina Ackerman, Kristin Burnett and Travis Hayin (eds), Transcending Borders: Abortion in the Past and Present (Cham: Palgrave Macmillan, 2017), $103-119$.

${ }^{79}$ Romain Lecler, 'Le succès d' Histoires d'A, "film sur l'avortement": Une mobilisation croisée de ressources cinématographiques et militantes (enquête)' [The success of Histoires d'A, 'film on abortion': a crossmobilisation of cinematic and militant resources (survey)], Terrains \& travaux, 2, 13 (2007), 51-72; Hélène Fleckinger, 'Histoires d'A: Un moment de la lutte pour la liberté de l'avortement' [Histoires d'A: a moment in the struggle for abortion freedom], La revue documentaire, 22-3 (2010), 181-95.

80 Jean-Yves Le Naour and Catherine Valenti, Histoire de l'avortement (XIXe-XXe siècle) [A history of abortion, 19th-20th century] (Paris: Seuil, 2015). Post-1975 France, in turn, became a popular destination, second only to Britain, for Spanish women seeking abortions: Agata Ignaciuk, 'Abortion travel and the cost of reproductive choice in Spain', in Sethna and Davis, op. cit. (note 65), 231-51. 


\section{New Reproductive Technologies}

The British development of IVF turned the spotlight on infertility and assisted conception just as Margaret Thatcher's Conservative government was reasserting traditional family values. ${ }^{81}$ The 'miraculous' birth of Louise Brown was a major medical and media event that came to signify the moment at which technologically assisted human reproduction became a reality. ${ }^{82}$ Katherine Dow's article in this issue examines To Mrs Brown... a Daughter (1978), a television documentary about Louise Brown, broadcast when she was just six weeks old. Dow presents information gleaned from her interview with Peter Williams, the film's producer, and finds that he sought to convince viewers that IVF was morally acceptable and to engender public sympathy for infertile couples. She argues that the broadcast helped to normalise IVF at a pivotal moment in its controversial history.

In the 1980s and 1990s, Britain's mainstream media and major marketing campaigns for new kinds of products focused more attention than ever on women's reproductive bodies: Victoria Gillick, a devoutly Catholic mother of ten, campaigned against the provision of contraception to minors; Mary Whitehouse railed against sex on television; New Labour renewed the government's commitment to tackling 'teenage pregnancy'; unmarried mothers topped the political agenda as both a drain on the welfare state and a moral threat; ${ }^{83}$ and pharmacies increasingly stocked home pregnancy tests, ovulation test kits and folic acid supplements for women of childbearing age. ${ }^{84}$ The AIDS 'epidemic' mobilised a younger generation of activists and politicians, and renewed enthusiasm for the condom; ${ }^{85}$ and the birth of Dolly the cloned sheep, near Edinburgh in 1996, elevated concerns that human cloning would not be far behind. ${ }^{86}$

${ }^{81}$ Martin Durham, Sex and Politics: The Family and Morality in the Thatcher Years (Basingstoke: Macmillan, 1991); Sarah Franklin, Celia Lury and Jackie Stacey (eds), Off-centre: Feminism and Cultural Studies (London: Routledge, 1991); Naomi Pfeffer, The Stork and the Syringe: A Political History of Reproductive Medicine (Cambridge: Polity, 1993); Franklin, Embodied Progress: A Cultural Account of Assisted Conception (London: Routledge, 1997); Nick Hopwood, 'Artificial fertilization', in Hopwood et al., op. cit. (note 6), 581-96.

82 Katherine Dow, “'Now She's Just an Ordinary Baby”: The Birth of IVF in the British Press', Sociology, Epub ahead of print: 22 February 2018, https://doi.org/10.1177/0038038518757953.

83 Jane Pilcher, 'Gillick and after: children and sex in the 1980s and 1990s', in Jane Pilcher and Stephen Wagg (eds), Thatcher's Children? Politics, Childhood and Society in the 1980s and 1990s (London: Routledge, 1996); Kathleen Kiernan, Hilary Land and Jane Lewis, Lone Motherhood in Twentieth-Century Britain: From Footnote to Front Page (Oxford: Oxford University Press, 1998); Lisa Arai, Teenage Pregnancy: The Making and Unmaking of a Problem (Bristol: Policy, 2009); Pat Thane and Tanya Evans, Sinners? Scroungers? Saints? Unmarried Motherhood in Twentieth-Century England (Oxford: Oxford University Press, 2012).

${ }^{84}$ Salim Al-Gailani, 'Making Birth Defects "Preventable": Pre-Conceptional Vitamin Supplements and the Politics of Risk Reduction', Studies in History and Philosophy of Biological and Biomedical Sciences, 47 (2014), 278-89; Jesse Olszynko-Gryn, 'Thin Blue Lines: Clearblue and the Rise of Pregnancy Testing in British Cinema and Television', British Journal for the History of Science, 50, 3 (2017), 495-520. On parallel developments in America: Jenna Healey, 'Sooner or Later: Age, Pregnancy and the Reproductive Revolution in Late Twentieth Century America' (unpublished $\mathrm{PhD}$ thesis, Yale University, 2016).

85 Verginia Berrige, AIDS in the UK: The Making of Policy, 1918-94 (Oxford: Oxford University Press, 1996); Hannah J. Elizabeth, 'Love Carefully and Without "Over-Bearing Fear": The Persuasive Power of Authenticity in Late 1980s British AIDS Education Material for Adolescents', Social History of Medicine, forthcoming. French virologist Luc Montagnier isolated HIV and linked it to AIDS in the 1980s. On the French history: Mirko D. Grmek, History of AIDS: Emergence and Origins of a Modern Pandemic (Princeton: Princeton University Press, 1990); Patrice Pinell (ed.), Une épidémie politique: la lutte contre le SIDA en France, (1981-96) [A political epidemic: the struggle against AIDS in France (1981-96)] (Paris: Presses universitaires de France, 2002).

86 Sarah Franklin, Dolly Mixtures: The Remaking of Genealogy (Durham: Duke University Press, 2007); Miguel García-Sancho, 'Animal Breeding in the Age of Biotechnology: The Investigative Pathway Behind the Cloning of Dolly the Sheep', History and Philosophy of the Life Sciences, 37, 3 (2015), 282-304. For the more general relevance of animal breeding to human reproductive medicine, including in France and 
The same period saw significant legislative reforms. In 1982, the British government established the Committee of Inquiry into Human Fertilisation and Embryology, presided over by moral philosopher Mary Warnock. Her 1984 report recommended allowing IVF and gamete donation in (heterosexual) marriage as well as research on human embryos up to two weeks old. ${ }^{87}$ The Surrogacy Arrangements Act 1985 outlawed commercial surrogacy, and the Family Law Reform Act 1987 conferred paternity rights to the partner of a donor-inseminated woman. But the debate over embryo research became embroiled in abortion politics; doctors and scientists mobilised to stop the Unborn Children (Protection) Bill 1985 and to back the bill that became the Human Fertilisation and Embryology Act 1990, which implemented most of Warnock's recommendations. The HFEA was revised in 2008 to permit lesbian parents and single-mothers access to IVF and the Marriage (Same Sex Couples) Act 2013 recognised gay parenting. ${ }^{88}$

France established its first commercial sperm banks in the early 1970s, in public hospitals with minimal oversight; only later did professionals start pressing for a stronger legal framework. Their demands became more insistent in the 1980s, after IVF was introduced in France. ${ }^{89}$ In 1988, the French government created the Commission Nationale de Médecine et de Biologie de Reproduction (National Commission on Reproductive Biology and Medicine) to licence private and public clinics for trials on assisted conception, and in 1992 it took on the additional responsibility of prenatal genetic screening. Following intensive interest-group consultations, the government passed the 1994 statute on gamete donation and assisted conception that permitted such procedures on medical grounds due to infertility only in the case of heterosexual couples who were married or had lived together for some time. The statute additionally required the gamete to be donated anonymously from one couple to another and with consent of the partner. ${ }^{90}$

French scientists also developed the abortifacient RU-486 (Mifepristone) in the early

Britain: Sarah Wilmot (ed.), 'Between the Farm and the Clinic: Agriculture and Reproductive Technology in the Twentieth Century', a special issue of Studies in History and Philosophy of Biological and Biomedical Sciences, 38, 2 (2007).

${ }^{87}$ Michael Mulkay, The Embryo Research Debate: Science and the Politics of Reproduction (Cambridge: Cambridge University Press, 1997); Duncan Wilson, A History of British Bioethics (Manchester: Blackwell, 2014), 140-86.

${ }^{88}$ Martin H. Johnson and Nick Hopwood, 'Modern law and regulation', in Hopwood et al., op. cit. (note 6), 597-611.

${ }^{89}$ Carine Vassy, 'From a Genetic Innovation to Mass Health Programmes: The Diffusion of Down's Syndrome Prenatal Screening and Diagnostic Techniques in France', Social Science \& Medicine, 63 (2006), 2041-51; Vassy Carine, Sophia Rosman and Bénédicte Rousseaua, 'From Policy Making to Service use: Down's Syndrome Antenatal Screening in England, France and the Netherlands', Social Science \& Medicine, 106 (2014), 67-74; Fabrice Cahen and Jerome Wijland, Inventer le don de sperme. Entretiens avec Georges David, fondateur des CECOS [Inventing sperm donation. An interview with Georges David, founder of CECOS] (Paris: Editions Matériologiques, 2016); Cahen 'Obstacles to the establishment of a policy to combat infertility in France, c. 1920-50', in Gayle Davis and Tracey Loughran (eds), A Handbook of Infertility in History: Approaches, Contexts and Perspectives (Basingstoke: Palgrave Macmillan, 2017), 199-219.

90 Ilana Löwy, 'Assistance médicale à la procreation (AMP) et le traitement de la stérilité masculine en France' [Medically assisted procreation (MAP) and the treatment of male infertility in France], Sciences Sociales et Santé, 18, 4 (2000), 75-104; Laurence Tain, 'L'Hôpital, la femme et le médecin: la construction des trajectoires de fécondation in vitro' [Hospital, woman and doctor: the construction of IVF trajectories], Population, 56, 5 (2001), 811-44; Tain, 'Corps reproducteur et techniques procréatives: images, brouillages, montages et remueménage' [Reproductive bodies and reproductive techniques: images, interference, mounts and bustle], Cahiers du Genre, 34 (2003), 171-92; Löwy, 'Prenatal diagnosis, surveillance and risk', in Hopwood et al., op. cit. (note 6), 567-79; Löwy, Tangled Diagnoses: Prenatal Testing, Women, and Risk (Chicago: University of Chicago Press, 2018). 
1980s, a period that saw America's retreat from reproductive research and development. ${ }^{91}$ France approved RU-486 in 1988, and it was made available on the NHS, with little fanfare, in $1991 . .^{92}$ Predictably, the 'French abortion pill' was most strongly opposed in the United States. ${ }^{93}$ French Health Minister Claude Évin famously called it 'the moral property of women' after the state-controlled manufacturing company, fearing reprisals from militant anti-abortion groups, briefly discontinued production. ${ }^{94}$ Today, more than half of all abortions in France and Britain are not surgical, but pharmaceutical. ${ }^{95}$ Meanwhile, the birth of millions of 'miracle' babies worldwide has normalised IVF, ${ }^{96}$ but debates rage on, on both sides of the Channel and around the world, over the ethics and regulation of surrogacy, 'three-parent babies' and genetic screening. ${ }^{97}$

Bringing the special issue to a close, Isabelle Ville's contribution explores the past and present of prenatal genetic screening in France. Ville compares the activities of two multidisciplinary prenatal diagnosis centres (CPDPNs), one in a provincial setting and the other in Paris. Drawing on ethnographic fieldwork and national quantitative data, she shows that the harmonisation of practices described in official discourse is illusory; there are major variations in the number of authorisations for pregnancy termination due to fetal malformation. Rooted in local clinical cultures, these differences relate to methods of organisation, processes of deliberation and decision making, and varying levels of tolerance towards the risk of disability. Ville argues that the regulatory regime allows fetal medicine practitioners a certain amount of autonomy at the CPDPN level.

In sum, the contributions to 'Reproductive Politics in France and Britain' underscore the central role played by doctors and activists in shaping practice and public opinion in both countries. Doctors tried to shape reproductive politics through their relationship with politicians, actively taking part in lobby groups, but also increasingly through communicating new knowledge to their patients and the public at a more private level. Feminists, in turn, relied on medical arguments and adapted their communication strategies to distinctive national contexts. The articles show how doctors and lay activists mobilised newspapers, magazines and television to disseminate information, influence policymakers and bring radical ideas into the mainstream. Local differences within national contexts are also made apparent. And the border between France and Britain, we conclude, was

\footnotetext{
91 Olszynko-Gryn, op. cit. (note 31).

${ }^{92}$ Sharon Tabberer, 'Moving Between the Symbolic and the Mundane: The Introduction of the Abortion Pill RU486 into the NHS' (unpublished PhD thesis, Anglia Polytechnic University, 2000).

93 Adele Clarke and Theresa Montini, 'The Many Faces of RU486: Tales of Situated Knowledges and Technological Contestations', Science, Technology, \& Human Values, 18, 1 (1993), 42-78; Carole Joffe and Tracy A. Weitz, 'Normalizing the Exceptional: Incorporating the "Abortion Pill" into Mainstream Medicine', Social Science \& Medicine, 56 (2003), 2353-66.

94 Virginia Husting and Leslie King, 'Francophobia, Anti-Americanism: Narratives of the Trans-Atlantic Other in French and US News on Abortion-Related Issues', Cultural Studies Critical Methodologies, 5, 4 (2005), 1-25.

95 Sally Sheldon, 'The medical framework and early medical abortion in the UK: How can a state control swallowing?', in Rebecca J. Cook, Joanna N. Erdman and Bernard M. Dickens (eds), Abortion Law in Transnational Perspective: Cases and Controversies (Philadelphia: University of Pennsylvania Press, 2014), 189-209.

96 Sarah Franklin, Biological Relatives: IVF, Stem Cells and the Future of Kinship (Durham: Duke University Press, 2013).

${ }^{97}$ See, for example, Cathy Herbrand and Rebecca Dimond, 'Mitochondrial Donation, Patient Engagement and Narratives of Hope', Sociology of Health and Illness, 40, 4 (2017), 623-38; Nick Hopwood, 'Globalization', in Hopwood et al., op. cit. (note 6), 641-55.
} 
more porous than is typically apparent from nationally-focused studies: ideas, people and devices travelled in both directions; communication strategies were always able to evade the rule of law; contraceptive practices were surprisingly similar in both countries; and religion loomed large in debates on both sides of the channel. In practice, attending to communication turns out to be a useful means of following the politics of reproduction across all levels of society. It is our hope that the cross-channel, bilingual conversation represented in this special issue will be continued elsewhere. $\grave{A}$ suivre.... 